\title{
Worker Remittances Compared to Other Elements of External Financing and Their Impact on Economic Growth and Human Capital in Jordan (1979-2015)
}

\author{
Eyad Moufaq Alkousini \\ Department of Management Sciences, Al-Rashid International Private University, Damascus, Syria \\ Email address: \\ alkousinieyad@gmail.com
}

\section{To cite this article:}

Eyad Moufaq Alkousini. Worker Remittances Compared to Other Elements of External Financing and Their Impact on Economic Growth and Human Capital in Jordan (1979-2015). International Journal of Economics, Finance and Management Sciences.

Vol. 8, No. 5, 2020, pp. 194-204. doi: 10.11648/j.ijefm.20200805.14

Received: September 18, 2020; Accepted: September 30, 2020; Published: October 12, 2020

\begin{abstract}
The objective of this study is to measure the impact of the workers' remittances on economic growth in Jordan during the period 1979-2015 by enhancing human capital according to the theory of endogenous growth. For this purpose, time series analysis (cointegration tests and vector error correction model) is used. Corresponding it is found that all the series representing the variables are stationary at the first difference. The results also show that there are two cointegration vectors relating the variables. Therefore, the model was estimated using vector error correction model, which showed a long-term relationship between economic growth and explanatory variables. The estimate showed that there is a positive effect of statistical significance for each of the remittances of workers and foreign loans, and a positive effect that is not statistically significant for both foreign direct investment and foreign aid. The study concluded with several recommendations that we summarize regarding the importance of workers' remittances as an external source of financing, characterized by its relative stability, low costs and not being directly linked to any requirements, which makes it one of the most important external sources of financing in addition to a role in supporting the absorptive capacity of human capital and thus supporting economic growth and deepening the role of capital (capital deepening) and raise its productivity. On the other hand, the need to better direct the sources of external flows towards projects that support the absorptive capacity (knowledge, skills and experiences) of the workforce, by raising the proportion of foreign aid and foreign loans directed towards spending on education, training and skills acquisition, which enhances their role in the short and long term in economic growth as well as Towards capital projects, which may enhance the role of workers' remittances.
\end{abstract}

Keywords: Workers' Remittances, Human Capital, Economic Growth, Foreign Direct Investment, External Loans, Foreign Aid

\section{Introduction}

Worker remittances are part of the income that migrants earn abroad and send to their families. Its importance in developing countries has increased in the past few decades, as it currently constitutes one of the main sources of income in many countries. The World Bank indicated that in many developing countries, these remittances are more than three times the total official development assistance funds, and thus remittances are the main source of external capital flows, bypassing foreign aid, foreign direct investment, and exports [24]. Due to the increase in these amounts in recent years, remittances of migrant workers have become increasingly important to developing countries. Remittances are difficult to ignore and have become a necessary resource for many developing countries. According to the World Bank's Summary Report (2019), annual remittances to lowmiddle income countries in 2018 totaled 529 billion dollars. With an increase of $9.6 \%$ from the previous year, which amounted to 483 billion dollars. On the level of the main countries receiving remittances, India was 79 billion dollars, then China with 67 billion dollars, followed by Mexico with 36 billion dollars, the Philippines 34 billion dollars, and Egypt with 29 billion dollars. While the remittances received 
by Jordan amounted to more than 4 billion dollars in 2018 [31]. Although the amounts of funds transferred through the bank are easily tracked, these transactions represent only a small part of the total remittance movement. This is because many Remittances take place informally through unregulated remittance agencies or other unregulated channels, without any effect. According to a World Bank estimate (2006), if these informal channels were added, the total amount of remittances would be $50 \%$ higher than the official estimate. Many developing countries depend on external capital flows. For example, these payments exceed the GDP in Tonga, Lesotho and Jordan by more than $20 \%$, and more than $15 \%$ of the GDP of Albania, Nicaragua, Yemen and Moldova; In addition to constituting more than $10 \%$ of the GDP of Lebanon, El Salvador, Cape Verde and Jamaica; And more than $5 \%$ of the GDP of many countries including Morocco and the Dominican Republic. Thus, the importance of this source to Jordan is highlighted, as it is one of the developing countries in which external remittances constitute more than $20 \%$ of the GDP. Like other developing countries, the Jordanian economy suffers from a financing gap that is widening over time, which makes it necessary for Jordan to resort to external financing. According to World Bank data, Jordan's dependence on external sources of financing is increasing. In 2015, foreign aid to Jordan reached 2.152 billion US dollars, as well as foreign direct investment, which reached 1.6 billion dollars in (2015), worker remittances reached 5.3 billion dollars. Therefore, remittances of workers abroad constitute one of the important sources for Jordan, because these remittances can compensate for the financing gap that the Jordanian economy suffers from, just like foreign direct investment or other external financing sources such as foreign aid.

The research aims to know the importance of remittance flows to the Jordanian economy during the period (19792015). This research is important as it sheds light on workers' remittances in addition to the rest of the external financing elements in Jordan and its impact on economic growth, in addition to trying to find a guide on how these remittances affect and support human capital. In addition to the fact that this research is based on the endogenous growth theory that affects economic growth by deepening the role of human capital, physical capital, and technological progress, the focus of this article is on these two aspects and their interaction with workers' remittances. All of this may help decision-makers in Jordan to design a policy to enhance remittance flows, or it may provide them with better and more realistic clarity on the current status of these flows. Therefore, this study seeks to answer the following important question: Do remittances of workers abroad enhance economic growth in Jordan in addition to the answer to which sources of external financing are the most effective in promoting economic growth in addition to trying to reach confirmation of the impact of workers remittances by supporting human capital. In the second topic, the theoretical and applied dimensions of external remittances will be addressed, in the third topic the situation of external remittances in Jordan will be discussed. As for the study model, methodology and Econometrics analysis, it is covered by the fourth topic. Finally, the findings and recommendations will be addressed in the fifth topic.

\section{Literature Review}

It is believed that remittances help reduce the poverty rate, because the poor in developing countries are the largest part of migrants and those who transfer money, and this helps increase the income of the families to whom the money is transferred, and remittances can also lead to an increase in consumption. Remittances are also the preferred source over foreign loans because they are not obligated to repay the loan amount and interest. Moreover, the government cannot waste it because it sends directly to individuals. This allows remittances to be managed to increase recipient countries' economic growth and is more stable than foreign direct investment, which is particularly volatile in developing countries. In addition to the above, the emigration of unskilled workers may be beneficial to the country receiving remittances, since these unskilled workers are characterized by their abundance, so their loss is likely to be less important for the sending economy. $[25,26]$. It is also possible that it may lead to other benefits, which is the training of unskilled workers who travel abroad and return to their country after a few years. However, these benefits of remittances may be accompanied by some costs and negative effects, which may increase the inactivity of remittance recipients. This reduces labor force participation in the recipient country. It has also been suggested that since remittances are mainly used for daily consumption, the effect of remittances on savings and investment may be negligible [16]. In this way, remittances may have a negative effect on promoting economic growth, since inflows may increase the value of a country's currency, And reduce net exports.

The migration of educated and highly skilled workers "brain drain" hurts most developing countries, and there are two reasons. First, it is one of the scarcest resources in developing countries and this loss of human capital reduces productivity and economic growth. The second reason is the high costs and effort that the state incurred in educating them, in addition to the high cost of retraining alternatives, the international migration of skilled workers is likely to increase the problem of income distribution between rich and poor countries. To offset this effect, some economists have suggested a brain drain tax imposed on developed countries as compensation for developing countries for their loss of qualified workers. [25,26]. The previous discussion suggests that in theory, the effects of workers' remittances on economic growth may be ambiguous. The impact of remittances workers on economic growth may be in more than one way through multiple channels, including: (1) Its effect on labor supply, (2) Its effect on capital accumulation and investment, (3) Its effect on total factor productivity, (4) its effect on human capital. The relationship between remittances and economic growth in recipient economies is 
still the subject of debate among scholars and policymakers. Although there is a large amount of literature on the role of remittance, the primary question remains whether remittances affect the economic growth of recipient countries. Scholars are divided to explain the relationship between transfers and growth, and opinions revolved around two approaches to explain that mechanism, the national accounts approach, and the endo genous growth theory. The national accounts approach is based on the fact that the effect of Workers remittances on macroeconomic variables is through their direct and indirect effects on the balance of payments, trade deficit, exchange rate and inflation [7,17]. The direct effects are that remittances are an integral part of the national account, while the indirect effects are that remittances affect macroeconomic behaviors through their effect on the exchange rate and relative prices. In their view, remittances have a positive impact on the balance of payments more than other capital flows (such as financial aid, direct investment, or loans), because their use is not linked to specific investment projects with high import content, and they do not bear any interest nor have to be paid. Others argue that remittances are a constant source of foreign exchange compared to other private capital flows, and that for certain countries they exhibit an anti-cyclical character $[6,30]$. Advocates of this theory have long believed that unlike aid entering the economy through official accounts, remittances to the home country can be saved, consumed, or invested. Remittances boost growth by providing more foreign exchange and financing for commercial investment $[3,9,13]$. For this reason, most of the literature believes that remittances influence economic growth by increasing consumption, saving, or investment. Indeed, after reviewing numerous studies, Lucas (2005) believes that remittances may have already accelerated investment in Morocco, Pakistan and India. Conversely, those who advocate indirect benefits believe that remittances influence macroeconomic behavior by influencing exchange rates and relative prices The literature on this method claims that large amounts of remittances to developing countries will lead to exchange rate appreciation and inflationary pressures for recipient countries. Which leads to the "Dutch disease" case. Several studies indicate that remittances have a negative impact on economic variables such as the balance of payments, the exchange rate, inflation and exports, which leads to an increase in the real exchange rate, inflation and an increase in imports, which leads to a deficit in the balance of payments To summarize, the national accounts model provides insights into how remittances affect recipient countries' macroeconomic outcomes. It shows two channels through which remittances (as foreign income) affect growth through macroeconomic outcomes. Direct channels emphasize the positive effect of remittances as a source of inexpensive external capital flows, which can improve national account capacity, consumption, savings, and investment, thus stimulating aggregate output. Indirect channels use remittances to influence exchange rates and relative rates, underscoring the negative effects of remittances on macroeconomic behavior. Hence, the literature on the national account approach includes an ongoing discussion on the macroeconomic impact of remittances. Similar literature claims that remittances are external private income of recipient households and are receipts in the national current account of recipient countries. Its impact depends on how it is used in the national economy, as well as the institutional environment and existing institutions that can enhance its multiplier effect on the economy. As for the second model, which is the endogenous growth model, it believes that the growth of the gross national product depends on the total productivity of factors (technological progress), and the domestic inputs of physical capital and human capital under the assumption of constant returns. Proponents of the model believe that the impact of remittance growth is detected through factors that the endogenous growth theory focuses on human capital development, total factor productivity (TFP), technology diffusion and physical investment [5,23,25]. A large number of documents have demonstrated that the endogenous growth theory supports the following point of view: human capital development and technology diffusion enhance economic growth and development by influencing total factor productivity (TFP). For this reason, Romer (1990) claimed that the rate of factor productivity growth depends on the efficiency of a human capital [12]. Endogenous growth theory can bridge this gap by demonstrating that the effect of remittance growth is supplemented by overall factors of production and technology diffusion. As presented in 2011, the Endogenous growth theory illustrates the channel through which remittances can boost economic growth and development. The model's main argument is that remittances can boost economic growth by increasing human capital and productivity, and an important channel for achieving this is technology diffusion. In addition, Udah (2011) stated that the effect of remittances on economic growth is not a direct one, but rather a factor affecting human capital. The endogenous growth model uses factor productivity, human capital, and the interaction between human capital and remittances. This argument is that there is a positive relationship between per capita GDP and human capital, human capital and remittances, physical capital, labor, technology diffusion, and government capital expenditures on economic and social services. Remittances also improve human capital by increasing health and education resources $[4,18]$.

Remittances can also reduce local macroeconomic volatility and encourage more domestic investment [29]. in one word, these two methods attempt to demonstrate their interest in promoting economic growth through the effect of remittances on the balance of payments, human capital development, and technological diffusion in the economy of the recipient country. A review of these two theories shows that the two models are compatible, and are not mutually exclusive when explaining economic growth. However, current theoretical research has not yet determined the threshold at which subsequent transfers will have a negative effect on the real exchange rate and inflationary pressures. In 
addition, the literature remains silent regarding the conditional effects of other factors (eg influence of level of development, financial development in a country). It is not just about savings and investment, but the quality of the system, the policy environment, and the country's context are also critical factors in determining the impact of remittance growth. My view is that the lack of a theoretical method for investigating the channels and conditions under which remittances continue to influence growth and development has led to inconsistent statements about remittances and economic growth, and has led to a lack of general conclusions.

\section{Applied Studies}

Previous discussions indicate that in theory, the effects of workers' remittances on economic growth, poverty, and income distribution may be ambiguous. What about empirical evidence? The literature in recent years that has studied the economic effects of remittances has been many and varied. The study of Ratha emphasizes the increasing importance of remittances as a source of external funds for developing countries. His study found that remittances are the second largest source of external financing (after foreign direct investment) for these countries [27]. Edwards and Ureta studied the effects of remittances on education in El Salvador. The study found that Remittances have a significant impact on continued learning in schools, empirical evidence on the impact of remittances on economic growth, poverty and income inequality is more mixe [10]. The study of Catrinescu, Leon-Ledesma, Piracha and Quillin found a weak positive long-term effect of remittances on economic growth [8], as well as the studies of Faini, Taylor and Stark and Lucas found a positive relationship between remittances and growth $[11,28]$. According to Jongwanich's study on the effects of remittances on growth and poverty in selected countries in Asia and the Pacific, using the panel data for the period 1993-2000, the study found a small positive effect of remittances on growth, but they have a significant positive effect on poverty reduction [15]. Similarly, a recent study conducted world bank (2005) to 101 developing countries indicates that remittances have a positive and significant effect on poverty reduction, but no impact on economic growth. In a 2008 Pradhana et al study in a sample of 39 developing countries using panel data from 1980-2004, remittances were found to have a positive effect on economic growth. The same applies to the study of Magableh on Jordan during the period 1976-2013 using the vector error correction model (VECM). The main results showed a long-term positive relationship between economic growth and both capital, employment and remittances in Jordan [20]. Bino et al For the Jordanian economy for the time period 1976-2016 using the ARDL model, the results show that although the remittances of Jordanian workers represent a vital source of financial flows, they are not used to increase consumption by receiving families and have no effect on economic growth or the progress of the financial system. Instead, it leads to increased imports and the trade deficit. Richard Adams study using data from 76 developing countries, the paper found that the structure of migrants' skills is one of the determinants of remittances. Countries that export a greater proportion of highly-skilled (educated) migrants receive fewer remittances per capita than countries that export a greater proportion of low-skilled migrants. It also concludes that the level of poverty (in the labor-sending country) does not have a positive effect on the level of incoming remittances. In summary, the impact of remittances ranged in many studies from the positive impact on economic growth [1], such as Mohammad Salahuddin and Jeff Gow on data for Bangladesh, India, Pakistan and the Philippines during the period (1977-2012). He found a long-term and very important positive relationship between remittances and economic growth in These countries. However, there is little positive correlation between them in the short term [21]. In the study of Harsha Paranavithana on Sri Lanka data during the period (1977-2012) using a vector error correction model, the study found a positive direct and indirect relationship between workers remittances and long-term economic growth. However, Wald test results show that there is no short-term causal relationship between workers remittances and economic growth, either directly or indirectly [14]. The study of M. SayedAbouElseoud on Egypt for the period (1991-2014) concluded that there is a Cointegration between workers remittances and the macroeconomic variables. There is also a one-way causal relationship extending from workers' remittances to private capital formation, total exports, total imports, money supply, exchange rate, while there is a twoway causal relationship between workers 'remittances and each of private consumption, government spending and economic growth [19]. As for the studies that have found a negative relationship between workers remittances and economic growth, we mention AltinGjini's study for Eastern European countries during the period between (1996-2010) and the results of the study were as follows: Remittances had negative effects on growth in this area during the period that Was analyzed. 10\% increase in remittances decreases output by about $0.9 \%$ [2]. MdShoaib Ahmed's study found the same results for Bangladesh for the time period (1995-2006). Remittance inflows had a negative impact on growth and were statistically significant.

\section{Remittances of Workers in Jordan}

The Jordanian economy was greatly affected by the economic, political and social developments in the surrounding region, and this led to major changes in economic trends, taking advantage of the oil and economic boom that the Gulf Cooperation Council countries witnessed in the seventies of the last century, and Jordan has received foreign aid. However, this boom did not continue. In the early 1980s, oil prices and Gulf Cooperation Council revenues fell sharply, and as a result aid to Jordan decreased. This led to an increase in the government's dependence on foreign loans for its development policies, and foreign 
investments were not at the required level during that period, and remittances to Jordan were the basis for economic prosperity and the main source of foreign exchange reserves. The Center for Strategic Research (2012) noted that, compared to foreign aid and foreign direct investment, remittances are a relatively consistent major source of international capital flows. The Central Bank of Jordan (2014) reported that the ratio of remittances to domestic exports in 2012 was $47 \%$. The Jordanian government has recognized the economic importance of remittances. Therefore, the government has taken some measures to encourage employees to work abroad, especially in the Arab Gulf states, to increase the flow of remittances. Among these facilities, for example, the granting of public sector employees a civil service leave for a period of up to 10 years according to the Memorandum of Understanding and the bilateral agreement between the Gulf and Jordanian governments. In addition, in 2013, the government recently changed the name of the Ministry of Foreign Affairs to the Ministry of Foreign Affairs and Expatriates to reflect the increasing official interest in the importance of Jordanian citizens abroad and their important economic and social role in the country. The Institute for Migration Policy indicates that in 2012 Jordan ranked eighteenth in receiving remittances, as it accounted for $11.4 \%$ of GDP (3.6 billion US dollars in 2012), compared to $22 \%$ and fourth place in 2000. Total remittance flows to Jordan began About 600 million dollars in the first year of the 1978 study period, and it fluctuated up and down ranging from 600 million dollars in 1978 to 3510 million dollars in 2008, with an average annual growth rate of 8 per cent. The remarkable decline in remittances to Jordan in 1990 and 1991 in terms of volume and as a percentage of GDP is due to the direct return of 250,000 to 330,000 Jordanians and Palestinians to Jordan from Kuwait as a result of the Iraqi invasion in August 1990 [6]. remittances doubled between $2000(1,800 \mathrm{M}$ dollars) and 2012 (3800M dollars). In theory, remittances boost GDP growth, because remittances are an important source of income for many households in developing countries. Remittances are mainly used for daily expenses, housing construction, real estate purchases, medical care and education. Part of the transfer is to be saved and can be invested. Therefore, with the increase in the percentage of remittances in GDP, GDP growth will increase, as long as many uses of remittances form part of aggregate demand. In the second half of the eighties of the last century, when Arab workers in the Arab countries were gradually replaced by Asians in the Gulf countries and gradually returned to their countries, and this explains the decrease in the volume of remittances and their relative importance in the GDP. As of the end of 2016, Jordan ranked 23rd among the best remittance recipients in the world for the percentage of remittances to GDP, and 32nd for the volume of inward remittances in US dollars. These rankings are lower than the 2007 rankings, being 10 and 29 respectively (world bank database). Although the annual volume of remittances in US dollars has remained stable since 2008 (around 3.5-6.3 billion
USD dollars), the percentage of GDP has steadily decreased (from $15.75 \%$ in 2008 to $11.16 \%$ in 2016 ). However, GDP transfers are a more appropriate measure of remittances. However, the Jordanian economy today suffers from unprecedented conditions, including an influx of Syrian refugees due to the war, high rates of inflation and unemployment, and the reluctance of donor countries to provide direct aid to the government budget. These economic pressures, along with government debt, which accounts for around $95 \%$ of GDP, and the growing trade deficit, require the government to take drastic measures to adjust the economic structure while optimizing the use of current capital flows. Comparing remittances and foreign direct investment as a percentage of GDP shows that Jordan has always received more financial inflows from remittances than foreign direct investment except in 2006, a time when the government privatized many companies in which it had large and controlling ownership stakes. Given that the research will address the effectiveness of the rest of the external financing elements, we must take a glimpse of how external sources of funding are directed in Jordan, which will help us in analyzing the results.

Foreign direct investment, according to the World Bank, foreign investment inflows to Jordan amounted to about 1.6 billion dollars in 2015, and according to the UNCTAD report, these expenditures accounted for $3.2 \%$ of the volume of incoming flows to Arab countries, down by $1.3 \%$ from 2014, so that Jordan ranks seventh out of 22 countries, down one place from the previous year. Table 1 shows the sectoral distribution of Arab investments during the years 2003-2016 in Jordan.

Table 1. Sectoral distribution of Arab investments in Jordan between 20032016.

\begin{tabular}{lll}
\hline $\begin{array}{l}\text { The share of each sector } \\
\text { in total investments }\end{array}$ & Sector type & Sector / destination \\
\hline $76.39 \%$ & construction & Real estate \\
$6.45 \%$ & construction & Construction and building materials \\
$2.94 \%$ & Services & Financial services \\
$2.29 \%$ & Services & Telecommunications \\
$0.93 \%$ & Services & Alternative Energy \\
$0.91 \%$ & Services & Hotels and tourism \\
$0.54 \%$ & Services & Storage \\
$0.29 \%$ & Services & Transportation \\
$0.16 \%$ & Services & Business services \\
$0.06 \%$ & Services & Outer space and planets \\
$5.94 \%$ & Industrial & Chemicals \\
$1.00 \%$ & Industrial & Minerals \\
$0.62 \%$ & Industrial & Food and tobacco \\
$0.45 \%$ & Industrial & Consumer products \\
$0.45 \%$ & Industrial & Software and technology \\
$0.34 \%$ & Industrial & Industrial machines and equipment \\
$0.22 \%$ & Industrial & Fabric \\
$0.04 \%$ & Industrial & Plastic \\
\hline
\end{tabular}

Source: Investment Climate Report in the Arab Countries, The Arab Corporation for Guarantee of Investment and Export Credit.

From the table, it is noted that the construction sector dominated Arab investments in Jordan, reaching 83\%. The industrial sector came second with $9 \%$ and services third 
with $8 \%$. It is noticed that most of the investments went towards the construction sector, while the percentage directed to the industrial sector was weak, which limits the full use of these investments in projects that deepen the role of capital. As for foreign aid, Table 2 shows the distribution of foreign aid, as the budget support rate increased to $38 \%$ in the total five years of the total aid, and the rest of the aid is directed towards specific projects or linked to specific imports, which loses a large part of its developmental benefit.

Table 2. The volume and percentages of foreign aid directed to support the general budget and development projects.

\begin{tabular}{|c|c|c|c|c|c|c|c|c|c|}
\hline $\begin{array}{l}\text { Total aid } \\
\text { and debt } \\
(8)+(4)\end{array}$ & $\begin{array}{l}\text { Development } \\
\text { aid percentages } \\
\text { of total funding } \\
(9)\end{array}$ & $\begin{array}{l}\text { (8) Flexible loans } \\
\text { and aid for } \\
\text { development } \\
\text { projects }(7)+(6)\end{array}$ & $\begin{array}{l}\text { Flexible loans to } \\
\text { support } \\
\text { development } \\
\text { projects }(7) \\
\end{array}$ & $\begin{array}{l}\text { Aid to } \\
\text { support } \\
\text { development } \\
\text { projects }(6) \\
\end{array}$ & $\begin{array}{l}\text { Budget support } \\
\text { percentages of } \\
\text { total funding } \\
(5) \\
\end{array}$ & $\begin{array}{l}(4) \text { Flexible } \\
\text { loans and } \\
\text { budget support } \\
\text { aid }(3)+(2)\end{array}$ & $\begin{array}{l}\text { Flexible } \\
\text { loans to } \\
\text { support the } \\
\text { budget }(3) \\
\end{array}$ & $\begin{array}{l}\text { Aid to } \\
\text { support the } \\
\text { budget }(2)\end{array}$ & $\begin{array}{l}\text { the year } \\
\text { (1) }\end{array}$ \\
\hline 704.94 & $56 \%$ & 391.94 & 28.34 & 363.6 & $44 \%$ & 313 & 0 & 313 & 2011 \\
\hline 3051.4 & $68 \%$ & 2085.6 & 343.3 & 1742.3 & $32 \%$ & 965.74 & 599 & 366.74 & 2012 \\
\hline 2632.163 & $80 \%$ & 2105.1 & 295 & 1810.1 & $20 \%$ & 527 & 150 & 377 & 2013 \\
\hline 1919.867 & $41 \%$ & 788.34 & 70.34 & 718.00 & $59 \%$ & 1131.5 & 592.8 & 538.68 & 2014 \\
\hline 2540.081 & $55 \%$ & 1388.0 & 669.99 & 718.00 & $45 \%$ & 1152.0 & 613.4 & 538.68 & 2015 \\
\hline 10848.45 & $62 \%$ & 6759.1 & 6758.97 & 5352 & $38 \%$ & 4089.3 & 1955.2 & 2134.1 & Total \\
\hline
\end{tabular}

Source: Prepared by the researcher based on several reports of the Ministry of Planning and International Cooperation

As for foreign loans, the matter is similar to foreign aid, where $80 \%$ of these loans go to support the public budget deficit, and Table 3 shows the directive of foreign loans.

Table 3. Directing external loans according to sectors.

\begin{tabular}{|c|c|c|c|c|c|c|c|c|c|c|}
\hline percentage & 2017 & percentage & 2016 & percentage & 2015 & percentage & 2014 & percentage & 2013 & Description \\
\hline $80.20 \%$ & 9516.7 & $77.50 \%$ & 7985.7 & $74.80 \%$ & 7027 & $69.60 \%$ & 5590 & $62.50 \%$ & 4524.4 & Budget support \\
\hline $7.10 \%$ & 840.4 & $8.50 \%$ & 878.4 & $8.80 \%$ & 830 & $12.60 \%$ & 1014.6 & $15.40 \%$ & 1111.5 & Electricity and energy \\
\hline $3.00 \%$ & 359.1 & $3.50 \%$ & 358 & $4.00 \%$ & 375.3 & $4.70 \%$ & 378.2 & $5.90 \%$ & 425.9 & social services \\
\hline $4.00 \%$ & 474.1 & $4.20 \%$ & 431.6 & $4.40 \%$ & 411.1 & $5.00 \%$ & 402 & $5.90 \%$ & 425.9 & Water and sanitation \\
\hline $1.50 \%$ & 172.2 & $1.50 \%$ & 152.6 & $1.70 \%$ & 156.3 & $2.10 \%$ & 170.2 & $2.70 \%$ & 194.5 & education \\
\hline $1.20 \%$ & 144.6 & $1.40 \%$ & 147.9 & $1.60 \%$ & 151.5 & $2.10 \%$ & 168.6 & $2.50 \%$ & 179.4 & Health \\
\hline \multirow[t]{2}{*}{$3.00 \%$} & 360.2 & $3.30 \%$ & 344.8 & $4.70 \%$ & 438.8 & $3.80 \%$ & 306.6 & $5.20 \%$ & 372.7 & Other \\
\hline & 11867.3 & & 10299 & & 9390 & & 8030.2 & & 7234.3 & Total \\
\hline
\end{tabular}

Source: Prepared by the researcher based on several reports from the Jordanian Ministry of Finance

\section{Methodology}

The study is based on the theory of endogenous growth, in a simulation of the Romer model (1990), and by relying on Borenszteina et al (1998) and Makki (2004) who relied on the endogenous growth model, Borenszteina et al (1998) estimated the impact of foreign direct investment On the growth of five developing countries for the period (19781998) and reached a positive role for foreign direct investment on economic growth and overcoming the role of domestic investment. He attributed this to the ability of foreign investment to transfer new technology and deepen the role of capital. He also found that the interaction of foreign investment and human capital (by adding a limit representing the sum of their data) positively affects growth. As for the Makki study (2004), the trade variable (exports + imports) was added to Borenszteina et al (1998) to study the effect of foreign investment and the external sector on growth in 66 developing countries for the period (1979-2004). The study found that both variables contribute to driving economic growth. The study also indicated that reducing the rate of inflation, tax rates and government consumption would enhance economic growth in developing countries. The study explained the positive impact of foreign direct investment from investing enterprises using modern machinery and tools in production, transferring modern administrative methods and quality standards, training local work force and providing them with the necessary skills. On the other hand, the positive impact of local investment was interpreted as a result of national institutions updating their production, administrative and training tools and methods to maintain their competitiveness in the face of foreign institutions. There are other studies that used a endogenous growth model to determine the effect of variables believed to play a role in growth. Elmawazini et al (2015) dealt with the impact of the banking sector, and Haiss and Sumegi (2008) dealt with the impact of the insurance sector. The current study deals with the impact of workers' remittances on economic growth, as these components contribute to raising productive capacity by deepening the role of capital and raising the absorptive capacity (improving human capital and disseminating technology). Accordingly, the study form can be formulated as follows:

$$
G=f(R E, E D, F D I \cdot O D A \cdot H \cdot K \cdot A)
$$

Where (GNI): Gross National Income, (ODA): Foreign Aid, (FDI): Foreign Direct Investment, (RE): Employee 
Remittances, (L): Human Capital, (K): Domestic Investment, (GC): It must be noted that the GNI was used to express the growth variable according to a study (Eugenijus et al, 2013), while spending on education was used to express human capital according to both Elena (2014) and (Kwon, 2009). Government spending has been used as an indicator for fiscal policy and institutions according to Makki (2004) [22]. Since human capital has been expressed in spending on education, it is necessary to clarify how spending on education is directed in Jordan. Table 4 shows how spending on education in Jordan will be directed within five years. It is noted that current spending is dominated by a rate of up to $91 \%$, which reduces the desired benefit of spending on education and the rehabilitation of human capital.

Table 4. Education spending in the last five years in Jordan.

\begin{tabular}{|c|c|c|c|c|c|}
\hline $\begin{array}{l}\text { The ratio of the } \\
\text { capitalist to the total }\end{array}$ & $\begin{array}{l}\text { Capital spending on } \\
\text { education }\end{array}$ & Current ratio of total & $\begin{array}{l}\text { Current spending on } \\
\text { education }\end{array}$ & $\begin{array}{l}\text { Total spending on } \\
\text { education }\end{array}$ & year \\
\hline$\% 8.65$ & 74.5 & $\% 91.35$ & 786.5 & 860.9 & 2010 \\
\hline$\% 10.06$ & 107.1 & $\% 89.94$ & 957 & 1064 & 2011 \\
\hline$\% 4.69$ & 54 & $\% 95.31$ & 1098.2 & 1152.2 & 2012 \\
\hline$\% 6.24$ & 81.5 & $\% 93.76$ & 1224 & 1305.5 & 2013 \\
\hline$\% 9.66$ & 134.3 & $\% 90.34$ & 1255.7 & 1390 & 2014 \\
\hline$\% 12.71$ & 182.4 & $\% 87.29$ & 1252.2 & 1434.6 & 2015 \\
\hline$\% 8.79$ & 633.7 & $\% 91.21$ & 6573.5 & 72017.2 & Total \\
\hline
\end{tabular}

Source: General Budget Department

\section{Analysis Results}

The economic analysis of the study subject is based on time series data, and this analysis requires the estimation of the Econometrics relationships between the study variables. Accordingly, preliminary statistical tests must first be conducted to determine the appropriate method for estimating these relationships, and this includes testing the unit root for data for each time series included in the estimation of the Econometrics relationship. Table 6 refers to the results of the unit root test, as the results showed that all time series are stationary at the first degree (I (1)).

\section{Cointegration test}

The unit root test results showed that all the variables are static at the first difference, and this indicates the possibility of a complementary relationship between the variables in the long term. Johansen test is used to demonstrate the existence of this relationship. Table 8 Shows the results of the Maximal Eigen Value Test and the Trace Test. The null hypothesis is tested that states that there is no complementary vector between these variables. These tests also show the number of co-integration vectors between the study variables.

From Table 8 it is clear that there are at least two Cointegration vectors between the variables in the Maximum Eigenvalues as well as according to the Trace Test. Based on these results, work will be done to estimate the relationship in the short and long term using the vector error correction model (VECM), but before that the number of time slowdown periods must be chosen. The most widely used Schwartz criterion in this field was used to determine them. Table in Table 7 indicates the existence of one lags period.

Results of a vector error correction model (VECM) estimation:

The results of the Johansen test for cointegration indicated that there is an integration between the variables in the long term, and therefore this relationship will be estimated through the vector error correction model (VECM). To estimate this model, the model was formulated in equation (2) in the following linear logarithmic form:

$$
\Delta L N(G N I)_{t}=\alpha_{0}+\sum_{j=1}^{n} \alpha_{j} \Delta \ln (G N I)_{t-i}+\sum_{i=0}^{m} \alpha_{i} \Delta \ln X_{t-1}+\Psi E C T_{1}+U_{t}
$$

Where GNI denotes gross national income, Xt represents the explanatory variables which are foreign direct investment (FDI), foreign aid (ODA), external debt (ED), domestic investment $(\mathrm{K})$, human capital $(\mathrm{L})$, government spending (GC). Remittances of workers. (RE) As for LN, it is the natural logarithm, $\Delta$ represents the first difference, ECT is the error correction factor, and its coefficient represents the ratio of errors that are corrected in each time period, and thus it shows how quickly the dependent variable adapts in the short term to its value In the long term, we consider the relationship of the dependent variable to the explanatory variables. This requires that be negative and statistically significant. Table 9 shows the results of estimating the vector error correction model (VECM) using only one time lag period. Given the results of estimating the vector error correction model (VECM), there is a long-term relationship between the economic growth variable and the explanatory variables, as the estimation of the error correction factor coefficient was negative and statistically significant. This estimate $(-0.4 \%)$ indicates that economic growth needs about two and a half years to return to the long-term equilibrium position, taking into account the relationship of growth with the explanatory variables.

As for the model's long-term estimates, they were statistically significant at the level of $5 \%$, with the exception of the foreign aid and foreign direct investment variables, which showed a positive impact without statistical significance. This indicates a causal relationship moving from the explanatory variables to the dependent variable (GNI). The integral vector can be written in the form of an 
equation showing the long-term equilibrium relationship

between the variables in the model as follows:

$$
\operatorname{lnGNI}(-1)=-20.22+0.78 \operatorname{LnED}(-1)+0.08 \operatorname{LnFDI}(-1)+1.04 \operatorname{LnK}(-1)-1.07 \operatorname{LnL}(-1)+0.04 \operatorname{LnODA}(-1)+
$$

Equation No. (3) and Table 9 show the effect of the explanatory variables on economic growth. It is noted that all external funding sources have a positive impact. Statistical significance only for the variables of workers' remittances and foreign loans, without statistical significance for both foreign aid and foreign direct investment. As for the greatest impact on economic growth among the four factors of external sources of financing, they were respectively external loans, then workers remittances, followed by foreign direct investment and foreign aid, and the reason may be due to the effect. The reason may be due to the great impact of foreign loans is their use in bridging the deficit in the general budget, which makes the government able to implement financial policies, and the quality of institutions, which were referred to in the index, government consumption, which has a positive impact. As for workers' remittances, they were positive, and that is due to their great role in increasing the absorptive capacity of human capital, as they are spent on health and education, and their impact may also be due to individuals investing these funds, as these funds are not subject to the conditions that are subject to the rest of the external financing from Directing towards specific projects, such as foreign aid, or high costs, such as the costs of foreign loans. As for foreign direct investment, the nature of the projects established makes benefit Minimum of these projects is that they are construction projects that do not deepen the role of physical or human capital or spread technology in line with the theory of endogenous growth. Foreign aid may be directed in advance to concrete projects, one of the obstacles to fully benefiting from it, which is not found in the foreign remittances of workers, as it is not subject to any prior restrictions, and may be used by investment spending or to increase economic growth through the multiplier if directed towards consumption. The foregoing supports the theory of self-growth based on the fact that foreign direct investment contributes to growth through the transfer of advanced technology, thus "deepening the role of capital" by increasing the productive capacities, whether material or human, available. Foreign aid, in its various forms, also contributes to enhancing the absorptive capacity by directing it towards education and training and raising it to productive capacity by preparing and developing infrastructure projects. The results also indicate that human capital (measured by spending on education) has not played the required role in supporting growth, and this may be due to the lack of directing spending in a way that supports the absorptive capacity, improves the quality of education outcomes, and focuses on quantity rather than quality
(Shantayanan et al, 1996), (Abu Nurudeen et al, 2010). The matter that was referred to according to Table No. To see this, spending on education for the last five years in Jordan will be detailed in millions, and it is according to Table 4, which shows that the percentage directed to capital spending within the education sector does not exceed $9 \%$ of the total spending on education, It is a low percentage that does not help in enhancing absorptive capacity, and thus economic growth. In order to know the extent of the impact of workers' remittances on human capital and capital formation, the worker remittances variable will be dropped from the model to see the size of the changes that will occur in the physical and human capital formation.

Diagnostic tests :Diagnostic tests are carried out in order to ensure the quality of the model used for analysis and that it is completely free from Econometrics problems. Table 10 shows the results of these tests. It is noted that the Normality of Residuals Test has a probability value of 0.34 , which means that the null hypothesis cannot be rejected that states that the residuals of the model are normally distributed. As for the Serial Correlation test between the random errors, the results of the estimation showed that the probability value of the test is 0.24 , indicating that there is no serial correlation between the errors. As for the heteroskedasticity test, the probability value of the test in the model was (0.099) and it is not statistically significant, and therefore it can be concluded that there is no difference in the variance of random errors.

The second model:

In order to know the extent of the impact of workers' remittances on human capital and capital formation, the worker remittance variable will be dropped from the model to see the size of the changes that will occur in the physical and human capital formation. Table 12 shows the results of the Maximal Eigen Value Test and the Trace Test. The null hypothesis is tested, which states that there is no cointegration vector between these variables. These tests also show the number of co-integration vectors between the study variables.

From Table 12, it is clear that there is at least one cointegration vector between the variables in the Maximum Eigenvalues as well as according to the Trace Test. Based on these results, work will be done to estimate the relationship in the short and long term using a vector error correction model (VECM), in Table 11 indicating the existence of one lags period. From Table 13, the integral vector can be written in the form of an equation showing the long-term equilibrium relationship between the variables in the model as follows:

$$
\begin{aligned}
& \ln G N I(-1)=-27.47+1.17 \operatorname{LnED}(-1)+0.37 \operatorname{LnFDI}(-1)+1.18 \operatorname{Ln} K(-1)-1.85 \operatorname{Ln} \operatorname{L}(-1)+0.21 \operatorname{LnODA}(-1)+ \\
& \text { 2.41 } \operatorname{Ln} G C(-1)
\end{aligned}
$$

From equation No. (3) and (4), we can compare the effect

of dropping workers 'remittances from the model with the 
comparison shown in Table 5

Table 5. Comparison of the results of the first and second model.

\begin{tabular}{llll}
\hline The difference & second model & first model & model \\
\hline $0.78-$ & -1.85 & -1.07 & Human capital \\
0.14 & 1.18 & 1.04 & capital formation \\
\hline
\end{tabular}

It is noted about the dropping of workers' remittances from the model the amount of the decline of human capital and the increase of the negative impact, which supports our theory of the positive effect of remittances on strengthening human capital and thus supporting economic growth by increasing the absorptive capacity of the recipient economy, as for capital formation, it may be due to individuals 'choices between consumption And investment

\section{Conclusions}

1) Jordan's dependence on external sources of financing increased during the study period, which indicates that there are imbalances inherent in the structure of this economy on the one hand, and on the other hand evidence that this funding was not directed in a way that supports the real economic capabilities of the state necessary to reduce this dependence on both loans and aid External, and to enhance the flow of foreign investment on the other hand.

2) A high relative importance appeared for foreign loans, followed by workers' remittances, at a time when the importance of loans appeared in filling the deficit in the general budget and making the financial policy and institutions have a positive impact.

3) The importance of workers' remittances is positive and in statistical terms, and it is one of the best flows because it is characterized by relative stability more than the rest of the external financing elements in addition to being low in cost and not linked to any compulsory directives towards specific projects or importing resources against them

4) The results of the Error Correction Model showed that the error correction factor (speed of adjustment) is negative and has statistical significance, which indicates that economic growth in Jordan is affected by the explanatory variables used in the model in the long term. The speed of adjustment in economic growth to long-term equilibrium has reached $(40 \%)$, meaning that economic growth needs about two and a half years to return to equilibrium through its relationship with the independent variables of the model.

5) Foreign aid and foreign loans contributed to covering a significant part of the public budget deficit, which in turn strengthened the role of government expenditures in economic growth, and this was demonstrated by the positive, statistically significant effect of the fiscal policy variable (government expenditures).

6) Standard results showed a negative impact of human capital, represented by spending on education. It is noted that only $9 \%$ of this spending was directed towards capital spending in this sector, while the rest was directed towards current expenditures.

7) The study showed the importance of remittances workers in enhancing the absorptive capacity of human capital and thus supporting economic growth according to the theory of endogenous growth. This appeared through the high negative impact of the human capital factor in the model when dropping the factor remittances factor from the model

8) Reorienting external financing in a way that serves the deepening of physical capital and absorptive capacity, and on the other hand, correcting the distortions that marred previous years by gradually reducing the part of external financing directed to the current side of the general budget and gradually increasing the part directed towards capital projects, education, health and what supports foreign investment Direct as an infrastructure.

9) The financing elements are all interconnected with each other. Improving the quality of directing and using these resources enhances the impact of workers 'remittances to be optimized

10) Supporting human capital by increasing education capital expenditures, which deepens the utilization of these expenditures and supports the absorptive capacity of this important resource.

Table 6. Phillip-Perron Test Results.

\begin{tabular}{|c|c|c|c|c|c|}
\hline \multirow{2}{*}{ Variables } & \multicolumn{2}{|l|}{ Level } & \multicolumn{2}{|l|}{ 1st differ. } & \multirow[t]{2}{*}{ Integrated } \\
\hline & Intercept & intercept and trend & Intercept & intercept and trend & \\
\hline LN(GNI) & $0.520(0.985)$ & $-1.174(0.90)$ & $-3.914(0.0049 *)$ & $-5.619(0.0003 *)$ & $\mathrm{I}(1)$ \\
\hline LN(FDI) & $-1.80(0.374)$ & $-2.464(0.342)$ & $-7.349(0.0000 *)$ & $-7.245(0.0000 *)$ & $\mathrm{I}(1)$ \\
\hline LN(ODA) & $-2.792(0.0694)$ & $-2.66(0.257)$ & $-6.740(0.0000 *)$ & $-12.606\left(0.0000^{*}\right)$ & $\mathrm{I}(1)$ \\
\hline $\mathrm{LN}(\mathrm{ED})$ & $-2.004(0.283)$ & $-1.92(0.623)$ & $-4.614\left(0.0007^{*}\right)$ & $-4.813(0.0024 *)$ & $\mathrm{I}(1)$ \\
\hline $\mathrm{LN}(\mathrm{K})$ & $-0.316(0.912)$ & $-1.686(0.736)$ & $-5.457\left(0.0001^{*}\right)$ & $-5.687(0.0002 *)$ & $\mathrm{I}(1)$ \\
\hline $\mathrm{LN}(\mathrm{GC})$ & $1.430(0.998)$ & $-0.721(0.963)$ & $-3.686\left(0.0087^{*}\right)$ & $-3.881\left(0.0236^{*}\right)$ & $\mathrm{I}(1)$ \\
\hline LN(RE) & $-2.33(0.16)$ & $-2.62(0.28)$ & $-5.23\left(0.0001^{*}\right)$ & $-5.14\left(0.001^{*}\right)$ & $\mathrm{I}(1)$ \\
\hline
\end{tabular}

Values in parentheses represent (p-value) The null hypothesis is accepted with a $5 \%$ probability* 
Table 7. Results of choosing the number of lags periods.

\begin{tabular}{llll}
\hline Model & Lag & AIC & SC \\
\hline & 0 & -0.97 & -0.66 \\
& 1 & -8.04 & $-5.56^{*}$ \\
\hline
\end{tabular}

Indicates the optimum time lag period*

Table 8. Johansen's results for the study models variables.

\begin{tabular}{llllllll}
\hline \multirow{2}{*}{ Hypothesized } & Trace Test & & & \multirow{2}{*}{ Hypothesized } & Max-Eigen Test & \\
\cline { 2 - 3 } & Trace Statistic & Critical Value 5\% & Prob & & Max-Eigen Statistic & Critical Value 5\% & Prob \\
\hline None* & 194.8 & 159.52 & 0.0001 & None* & 55.51 & 52.36 & 0.023 \\
At most $1^{*}$ & 139.28 & 125.61 & 0.0056 & At most $1 *$ & 46.58 & 46.23 & 0.045 \\
At most 2 & 92.7 & 95.75 & 0.079 & At most 2 & 35.75 & 40.07 & 0.14 \\
\hline
\end{tabular}

Reject the hypothesis of non-integration at the $5 \%$ level of significance*.

Table 9. Results of estimating the causal relationship in the long and short term using the vector error correction model (VECM).

\begin{tabular}{lllllllll}
\hline Cointegrating Eq: & LNGNI(-1) & LNED(-1) & LNFDI(-1) & LNK(-1) & LNL(-1) & LNODA(-1) & LNGC(-1) & LNRE(-1) \\
\hline CointEq1 & 1.00 & $-0.79(-7.31)$ & $-0.08(-1.3)$ & $-1.04(-7.68)$ & $1.07(3.29)$ & $-0.04(-0.81)$ & $-1.58(-4.8)$ & $-0.24(-22.07)$ \\
c & 20.22 & ECT & $-0.4(-4.27)$ & & & & & \\
Cointegrating Eq: & D(LNGNI(-1)) & D(LNED(-1)) & D(LNFDI(-1)) & D(LNK(-1)) & D(LNL(-1)) & D(LNODA(-1)) & D(LNGC(-1)) & D(LNEL(-1)) \\
CointEq1 & $1.56(3.39)$ & $0.27(1.82)$ & $-0.03(-0.58)$ & $-0.4(-3.09)$ & $0.15(1.12)$ & $0.014(0.33)$ & $-0.78(-2.36)$ & $-0.07(-0.7)$ \\
R-squared & 0.53 & Adjusted R-squared & 0.36 & SC -4.60 & AIC & -8.51 & F-statistic & 3.176 \\
\hline
\end{tabular}

Table 10. Diagnostic tests.

\begin{tabular}{llllll}
\hline Normality Test & & \multicolumn{2}{l}{ Heteroskedasticity Test } & \multicolumn{2}{l}{ Serial Correlation Test } \\
\hline Jarque-bera & Prob. & F-statistic & Prob. & F-statistic & Prob. \\
\hline 2.1 & 0.34 & 1.93 & 0.099 & 1.46 & 0.24 \\
\hline
\end{tabular}

Table 11. Results of choosing the number of lags periods.

\begin{tabular}{llll}
\hline Model & Lag & AIC & SC \\
\hline 0 & -0.97 & -0.66 \\
& 1 & -8.04 & $-5.56^{*}$ \\
& 2 & $-8.17^{*}$ & -3.51 \\
\hline
\end{tabular}

Indicates the optimum time lag period.

Table 12. Johansen's results for the study models variables.

\begin{tabular}{llllllll}
\hline \multirow{2}{*}{ Hypothesized } & Trace Test & \multicolumn{5}{l}{ Mypothesized } & \multicolumn{2}{l}{ Max-Eigen Test } \\
\cline { 2 - 6 } & Trace Statistic & Critical Value 5\% & Prob & & Max-Eigen Statistic & Critical Value 5\% & Prob \\
\hline None* & 138.27 & 125.62 & 0.006 & None* & 46.52 & 46.23 & 0.046 \\
At most 1 & 91.74 & 95.75 & 0.0915 & At most 1 & 30.43 & 40.08 & 0.39 \\
\hline
\end{tabular}

Reject the hypothesis of non-integration at the $5 \%$ level of significance

Table 13. Results of estimating the causal relationship in the long and short term using the vector error correction model (VECM).

\begin{tabular}{llllllll}
\hline Cointegrating Eq: & LNGNI(-1) & LNED(-1) & LNFDI(-1) & LNK(-1) & LNL(-1) & LNODA(-1) & LNGC(-1) \\
\hline CointEq1 & 1.00 & $-1.17(-7.21)$ & $-0.38(-3.72)$ & $-1.18(-5.51)$ & $1.85(3.37)$ & $-0.04(-0.81)$ & $-2.41(-4.37)$ \\
c & 27.47 & ECT & $-0.24(-4.18)$ & & & & \\
Cointegrating Eq: & D(LNGNI(-1)) & D(LNED(-1)) & D(LNFDI(-1)) & D(LNK(-1)) & D(LNL(-1)) & D(LNODA(-1)) & D(LNGC(-1)) \\
CointEq1 & $1.35(3.53)$ & $0.15(1.06)$ & $-0.04(-0.85)$ & $-0.4(-3.14)$ & $0.21(1.49)$ & $0.011(0.26)$ & $-0.72(-2.25)$ \\
R-squared & 0.51 & Adjusted R- squared & 0.36 & SC -4.44 & AIC-7.55 & F-statistic & 3.46 \\
\hline
\end{tabular}

Table 14. Diagnostic tests.

\begin{tabular}{llllll}
\hline Normality Test & & \multicolumn{2}{l}{ Heteroskedasticity Test } & \multicolumn{2}{l}{ Serial Correlation Test } \\
\hline Jarque-bera & Prob. & F-statistic & Prob. & F-statistic & Prob. \\
\hline 1.98 & 0.37 & 1.32 & 0.27 & 1.41 & 0.26 \\
\hline
\end{tabular}




\section{References}

[1] Adams, Richard. (2008). "The Demographic, Economic and Financial Determinants of International Remittances in Developing Countries". World Bank. 4583.

[2] AltinGjini (2013), The Role of Remittances on Economic Growth: An Empirical Investigation Of 12 CEE Countries,International Business \& Economics Research Journal, Volume 12, Number 2.

[3] Amuedo-Dorantes, C., \& Pozo, S. (2006). Remittance receipt and business ownership in the Dominican Republic. The World Economy, 29 (7), 939-956.

[4] Amuedo-Dorantes, C., Georges, A., \& Pozo, S. (2008). Migration, remittances, and children's schooling in Haiti. The Annals of the American Academy of Political and Social cience, 630 (1), 224-244.

[5] Benhabib, J., \& Spiegel, M. M. (1994). The role of human capital in economic development evidence from aggregate cross-country data. Journal of Monetary Economics, 34 (2), $143-173$.

[6] Buch, C., Kuckulenz, A., \& Le Manchec, M. (2002). Worker remittances and capital flows. Kiel working paper no. 1130. Kiel: Kiel Institute for World Economics.

[7] C., \& Kuckulenz, A. (2004). Worker remittances and capital flows to developing countries. Centre for European Economic Research (ZEW) discussion paper 04 31. Mannheim: ZEW.

[8] Catrinescu, N., Leon-Ledesma, M., Piracha, M., and Quillin, B. (2005), IZA Discussion Paper No. 2139. http://ssrn.com/abstract 1/4 902342.

[9] Edwards, A. C., \& Ureta, M. (2003). International migration, remittances, and schooling: Evidence from El Salvador. Journal of Development Economics, 72 (2), 429-461.

[10] Edwards, A., and Ureta, M. (2003), 'International Migration, Remittances, and Schooling: Evidence from El Salvador,' NBER Working Paper No. w 9766, June.

[11] Faini, R. (2001), Development, Trade, and Migration, Washington, DC: IMF.

[12] Gapen, M. T., Chami, M. R., Montiel, M. P., Barajas, M. A., \& Fullenkamp, C. (2009). Do workers' remittances promote economic growth? (No. 9-153). International Monetary Fund.

[13] Gitter, S. R., \& Barham, B. L. (2007). Credit, natural disasters, coffee, and educational attainment in rural Honduras. World Development, 35 (3), 498-511.

[14] HarshaParanavithana (2014), Do Workers' Remittances Cushion Economic Growth in Sri Lanka?, International Journal of Business and Social Science Vol. 5, No. 10 (1).

[15] Jongwanich, J. (2007), 'Workers' Remittances, Economic Growth and Poverty in Developing Asia and the Pacific Countries,' UNESCAP Working Paper WP/07/01, Bangkok: ESCAP.
[16] Kapur, D., and McHale, J. (2005)," Give Us Your Best and Brightest: The Global Hunt for Talent and Its Impact on the Developing World", Washington, DC: Center for Global Development.

[17] Kireyev, M. A. (2006). "The macroeconomics of remittances: The case of Tajikistan". IMF working papers no 06/2. Washington: DC. International Monetary Fund.

[18] Lucas, R. E. (2005). International migration and economic development: Lessons from low-income countries. Edward Elgar Publishing. Sweden.

[19] M. SayedAbouElseoud (2014), Do Workers' Remittances Matter for the Egyptian Economy, International Journal of Applied Operational Research Vol. 4, No. 1, pp. 1-26.

[20] Magableh. Sohail. (2017)." Inflow Remittances and Economic Growth". Jordan Journal of Economic Sciences. Volume 4.

[21] Mohammad Salahuddin and Jeff Gow (2015), the relationship between economic growth and remittances in the presence of cross- sectional dependence, the Journal of developing arias, Volume 49 No. 1.

[22] Makki, S. (2004)."Impact of Foreign Direct Investment and Trade on Economic Growth",American Journal of Agricultural Economics vol. 86, issue 3, 795-801.

[23] Nelson, R. R., \& Phelps, E. S. (1996). Investment in humans, technological diffusion, and economic growth. American economic association papers and proceedings May 75) 69.

[24] Nsiah, Christian and Bichaka Fayissa. (2013). "Remittances and economic growth in Africa, Asia, and Latin AmericanCaribbean countries: a panel unit root and panel ointegration analysis".

[25] Perkins, D., Radelet, S., Snodgrass, D., Gillis, M., and Romer, M. (2001)," Economics of Development (5th ed.)", New York: W. W. Norton \& Company.

[26] Pradhana, Gyan. Upadhyayb, Mukti. Upadhyaya, Kamal. (2008). "Remittances and economic growth in developing countries". European Journal of Development. 20:3,497-506.

[27] Ratha, D. (2003), 'Workers' Remittances: An Important and Stable Source of External Development Finance,' Global Development Finance, World Bank, 157-175.

[28] Stark, O., and Lucas, R. (1988), 'Migration, Remittances and the Family,' Economic Development and Cultural Change, 36, $3,465-481$.

[29] Taylor, J. E. (1992), 'Remittances and Inequality Reconsidered: Direct, Indirect and Intertemporal Effects,' Journal of Policy Modeling, 14, 2, 187-208.

[30] Udah, E. B. (2011). Remittances, human capital and economic performance in Nigeria. International Journal of Human Development and Sustainability, 4 (1), 103-117.

[31] World Bank. 2019. " MIGRATION AND DEVELOPMENT". BRIEF 31 April. 